\title{
Infectious Complications of Hematopoietic Stem Cell Transplantation
}

\section{Shiksha Kedia ${ }^{1}$, Pranab Sharma Acharya ${ }^{1}$, Farhan Mohammad ${ }^{1}$, Huy Nguyen ${ }^{1}$, Deepak Asti ${ }^{1}$, Suchita Mehta ${ }^{1 *}$, Manisha Pant ${ }^{2}$ and Neville Mobarakai $^{3}$}

${ }^{1}$ Department of Medicine, Staten Island University Hospital, Staten Island, New York, USA

${ }^{2}$ Department of Medicine, College of Medical Sciences, Bharatpur, Nepal

${ }^{3}$ Associate Program Director, Department of Medicine and Infectious Disease, Staten Island University Hospital, Staten Island, New York, USA

Abbreviations: EBV: Epstein-Barr Virus; HHV6: Human Herpes Virus 6; PTLD: Post Transplant Lymph- proliferative Disease

\section{Introduction}

Hematopoietic stem cell transplantation (HSCT) has been one of the revolutionary discoveries in the world of science leading to cure of many of the hematological malignancies and for several nonmalignant conditions. It involves harvesting of stem cells from either the bone marrow most traditionally, peripheral blood or umbilical cord and then transplanting them into a recipient [1-3]. This could be either allogeneic i.e. from another donor or autologous i.e. from the patient himself $[1,4]$. The first successful series of autologous HSCT for lymphoma was reported in 1978 [5]. With a better understanding of immunological mechanisms and molecular sciences, it has now been possible to decrease the rates of rejection due to incompatibility thereby improving overall graft survival many fold. Today, more than 50.000 transplants are carried out annually worldwide and the numbers are increasing each year [6].

Despite all the advances in this field, it does remain to be a procedure with several potential complications, infectious being one of the major ones. The type of transplant influences the risk of infection and graft versus host disease (GVHD) in stem cell recipients. This is shown in the table 1 [7].

Immediately after transplantation, irrespective of implementation of myeloablative regimen, there is a period of pancytopenia and thus patients are most prone to febrile neutropenia in this phase. This is the pre-engraftment phase which usually spans from few days to three to four weeks depending on the type of transplant [8]. This phase is shorter and milder in severity in patients with non-myeloablative regimen for the transplant [9].

Myeloblative regimens are associated with significant mucosal damage in the oral cavity and gastrointestinal tract and this increases the transmigration of organisms, increasing the rates of bacteremia and infection [10].

Engraftment is characterized by a stable growth and circulation of hematopoietic stem cells, this process requiring adequate immunosuppression of the host, CD34 cells and also donor T cells to prevent graft rejection [11,12]. Engraftment period is usually from 3 weeks to 3 months. After the 3 months begins the post-engraftment phase during which $\mathrm{T}$ cells recover. In this phase the presence of chronic graft versus host disease are at a higher risk of infectious complications [13]. The infections that are commonly seen in these various phases of transplantation are shown in figure 1 below [14].

\section{Bacterial Infections}

As previously mentioned above, bacterial infections are the most prevalent pathogens during the pre-engraftment phase and can be rapidly fatal if not promptly treated. The increased risk of bacterial infections can be contributed to the immediate neutropenia that is characteristic of this phase, as well as the presence of indwelling catheters and mucosal injury from the preparative regimen [15].

Mucosal injury, which occurs because of the conditioning regimen, leads to translocation of bacteria and approximately $40 \%$ of these infections are due to gram-negative organisms, which include Pseudomonas, Enterobacter, Escherichia coli, and Klebsiella [16]. Whereas, gram-positive bacteria especially Staphylococcus (S) epidermidis, Streptococcus viridans and S. aureus colonize venous catheters often leading to bacterimia requiring prompt initiation of appropriate antibiotics, however, removal of the catheter may be necessary to reduce the inoculum. Clostridium Difficile colitis is also of particular concern due to the use of chemotherapy and antibiotics in patients undergoing HSCT. Empiric broad-spectrum antibiotics should be initiated whenever there is a fever in a neutropenic patient. A carbipenem such as imipenem or meropenem, or cephalosporin such as cefepime and ceftazidime are effective as a single agent in patients without severe sepsis or neutropenia [17].

If there is no resolution of fever after 4 days, antifungal therapy should be started [18].

The addition of a second agent such as an aminoglycoside is indicated if resistance is suspected or if the patient is severely neutropenic.

Good hand-hygiene and daily use of antibiotics during the neutropenic phase are adopted principles of preventive measures. A fluoroquinolone and/or trimethoprim-sulfamethoxazole are accepted choices. These antibiotics should be continued until neutropenia resolves and immunosuppressive therapies discontinued [15]. In the post-engraftment phase, presence of GVHD poses an additional risk for bacterial infections especially with enteric organisms. After three months of HSCT, infections with encapsulated bacteria are seen due to poor opsonization related with chronic GVHD. Nocardia, Mycobacterium tuberculosis, and atypical mycobacteria, though infrequent also should be considered as possibility in the post engraftment phase especially in the setting of a new pulmonary infiltrate or nodule.

\section{Parasitic Infections}

Parasitic infection in HSCT is usually via reactivation; therefore,

*Corresponding author: Suchita Mehta, Department of Medicine, Staten Island University Hospital, Staten Island, New York, USA, Tel: 718-226- 6158; E-mail: mehtasuchita@gmail.com

Received April 30, 2013; Accepted May 30, 2013; Published June 01, 2013

Citation: Kedia S, Acharya PS, Mohammad F, Nguyen H, Asti D, et al. (2013) Infectious Complications of Hematopoietic Stem Cell Transplantation. J Stem Cell Res Ther S3:002. doi:10.4172/2157-7633.S3-002

Copyright: () 2013 Kedia S, et al. This is an open-access article distributed under the terms of the Creative Commons Attribution License, which permits unrestricted use, distribution, and reproduction in any medium, provided the original author and source are credited. 
Citation: Kedia S, Acharya PS, Mohammad F, Nguyen H, Asti D, et al. (2013) Infectious Complications of Hematopoietic Stem Cell Transplantation. J Stem Cell Res Ther S3:002. doi:10.4172/2157-7633.S3-002

Page 2 of 8

\begin{tabular}{|c|c|c|c|c|c|}
\hline $\begin{array}{l}\text { Type of Hematopoietic } \\
\text { Stem Cell Transplant }\end{array}$ & Source of Stem Cells & $\begin{array}{l}\text { Risk of Early Infection: } \\
\text { Neutrophil Depletion }\end{array}$ & $\begin{array}{l}\text { Risk of Late } \\
\text { Infection: } \\
\text { Impaired T and B } \\
\text { Cell Function }\end{array}$ & $\begin{array}{l}\text { Risk of Ongoing Infection: GVHD and } \\
\text { latrogenic Immunosuppression }\end{array}$ & $\begin{array}{l}\text { Graft versus } \\
\text { Tumor } \\
\text { Effect }\end{array}$ \\
\hline Autologous & Recipient (self) & $\begin{array}{l}\text { High risk; neutrophil recovery } \\
\text { sometimes prolonged }\end{array}$ & $\sim 1$ year & $\begin{array}{l}\text { Minimal to no risk of GVHD and late-onset } \\
\text { severe infection }\end{array}$ & None (-) \\
\hline Syngeneic (genetic twin) & Identical twin & $\begin{array}{l}\text { Low risk; } 1-2 \text { weeks for } \\
\text { recovery }\end{array}$ & $\sim 1$ year & $\begin{array}{l}\text { Minimal risk of GVHD and late-onset severe } \\
\text { infection }\end{array}$ & $+/-$ \\
\hline Allogeneic related & Sibling & $\begin{array}{l}\text { Low risk; } 1-2 \text { weeks for } \\
\text { recovery }\end{array}$ & $\sim 1$ year & $\begin{array}{l}\text { Minimal to moderate risk of GVHD and late- } \\
\text { onset severe infection }\end{array}$ & ++ \\
\hline Allogeneic related & $\begin{array}{l}\text { Child/ } \\
\text { parent(haploidentical) }\end{array}$ & $\begin{array}{l}\text { Intermediate risk; } 2-3 \text { weeks } \\
\text { for neutrophil recovery }\end{array}$ & $1-2$ years & $\begin{array}{l}\text { Moderate risk of GVHD and late-onset severe } \\
\text { infection }\end{array}$ & ++++ \\
\hline Allogeneic unrelated adult & Unrelated donor & $\begin{array}{l}\text { Intermediate risk; } 2-3 \text { weeks } \\
\text { for neutrophil recovery }\end{array}$ & $1-2$ years & $\begin{array}{l}\text { High risk of GVHD and late-onset severe } \\
\text { infection }\end{array}$ & ++++ \\
\hline $\begin{array}{l}\text { Allogeneic unrelated cord } \\
\text { blood }\end{array}$ & $\begin{array}{l}\text { Unrelated cord blood } \\
\text { units }(x 2)\end{array}$ & $\begin{array}{l}\text { Intermediate to high } \\
\text { risk; neutrophil recovery } \\
\text { sometimes prolonged }\end{array}$ & Prolonged & $\begin{array}{l}\text { Minimal to moderate risk of GVHD and late- } \\
\text { onset severe infection }\end{array}$ & ++++ \\
\hline $\begin{array}{l}\text { Allogeneic mini } \\
\text { (nonmyeloablative) }\end{array}$ & $\begin{array}{l}\text { Donor (transiently } \\
\text { coexisting with recipient } \\
\text { cells) }\end{array}$ & $\begin{array}{l}\text { Low risk; neutrophil counts } \\
\text { close to normal }\end{array}$ & $1-2+$ years & $\begin{array}{l}\text { Variable risk of GVHD and late-onset severe } \\
\text { infection }\end{array}$ & $\begin{array}{l}++++ \text { (but } \\
\text { develops } \\
\text { slowly) }\end{array}$ \\
\hline
\end{tabular}

Table 1: Infection risk associated with type of transplant.

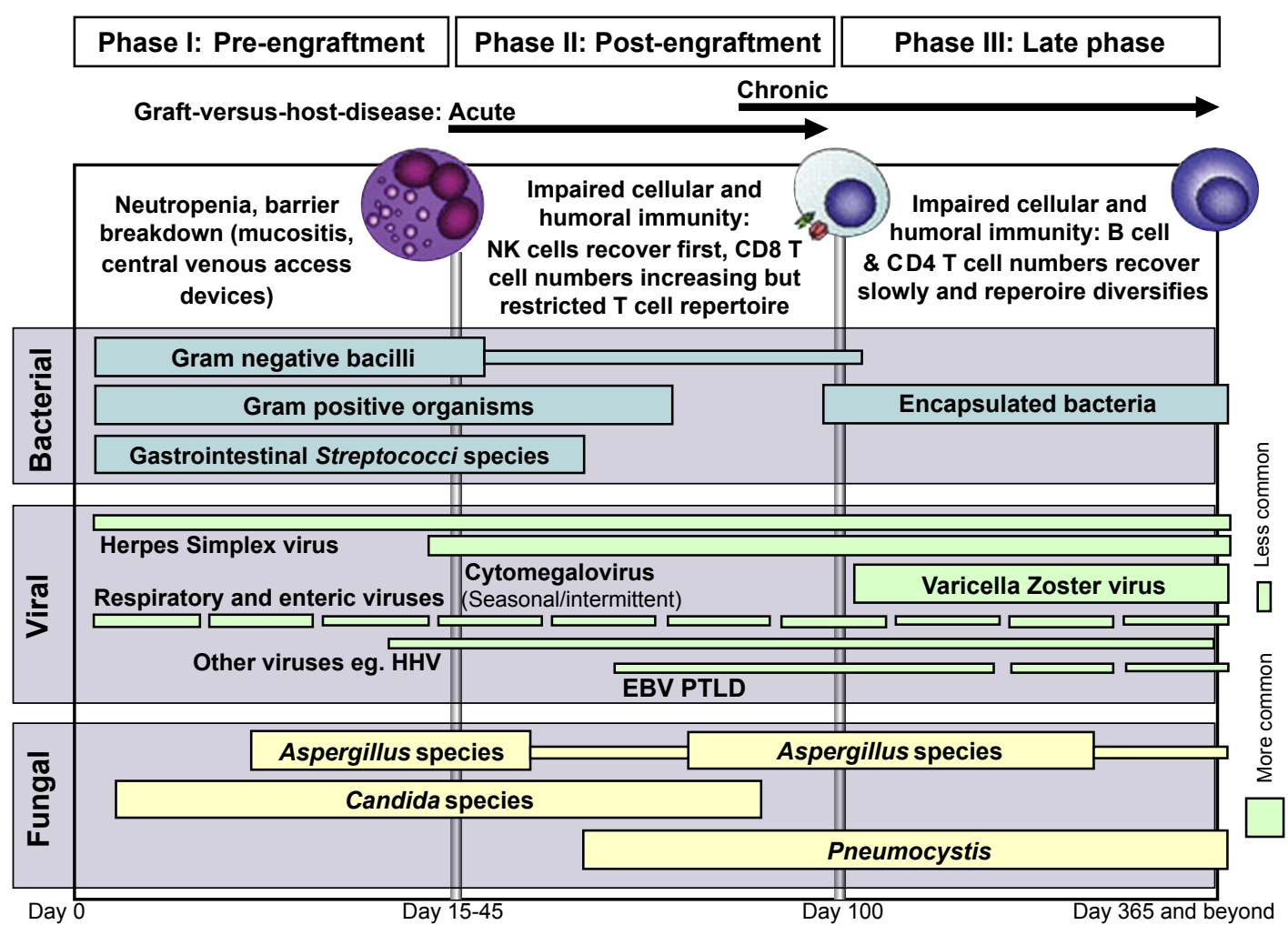

Figure 1: Phases of opportunistic infections among allogeneic HSCT recipients.

it is crucial to use prophylaxis whenever indicated and to perform good screening for patients at risk such as those who lived in or have traveled to endemic regions. Strongyloides stercolaris is endemic in tropical regions, in the United States (US) it is found in the south east [19]. It is usually asymptomatic in majority of the patients, and in some can cause an urticarial like rash and persistent dry cough if it migrates to the lungs. However, in the immunsuppressed host it can lead to hyperinfection, septic shock with multiorgan system failure [20]. The treatment and prophylaxis of parasitic infections can include antiparasitics such as albendazole and ivermectin, and Trimethoprimsulfamethoxazole.

\section{Fungal Infections}

The incidence of fungal infections is around $10 \%-20 \%$ after the transplantation [21]. Fungal infections can cause a high mortality following HSCT, particularly allogenic grafts, because of receiving post transplantation immunosuppressive medications [22-24]. However, it varies in different transplantation centers depending on various factors like the geographical region, period of neutropenia, type of transplant (allogenic or autologous), Humman Leukocyte Antigen (HLA) matching, relatedness of the donor, type of stem cells (peripheral blood, cord blood or bone marrow) and type of prophylactic treatment 
used. With the lack of sensitivity of the cultures, the diagnosis of fungal infections is a big challenge and most often has to be relied on clinical signs, radiological features and histopathology.

Yeasts and molds are the most common pathogens seen after HSCT, followed by zygomycetes, Fusarium species and Scedosporium species $[25,26]$. Reactivation of endemic fungi such as histoplasmosis, blastomycosis and coccidomycosis, though very uncommon should be considered in patients after HSCT.

Candida (C) albicans is the most common isolate, although the incidences of candida non-albicans have raised in recent years partly as a result of prophylaxis used against candida albicans [27]. Among the mold pathogens, Aspergillus is the most common genus causing the fatal invasive disease in immunecompromised host. Mucormycosis is infrequent, but can cause life threatening rhinoorbital, cerebral, pulmonary and disseminated disease.

The most common fungal pathogen during pre-engraftment period is candida albicans. With the breakdown of the mucosa of the gastrointestinal (GI) tract because of GVHD and chemotherapy, candida colonisers can invade the tissues and cause invasive candidiasis. C. glabrata and C. krusei can also cause invasive disease, in the setting of mucositis $[28,29]$. Flucanozole is the most common prohylactic antifungal. A metaanalysis study involving 64 randomised controlled trials showed that use of anti-fungal prophylaxis decreased invasive fungal infections by 50 percent [30].

During immediate and late post engraftment, the most common fungal infection is Invasive Aspergillosis (IA) secondary to increased risk of GVHD and prolonged use of corticosteroids. Pnemocystis jiroveci is another fungus, which occurs very late after transplantation and can present as pneumonitis, but can effectively prevented by the use of trimethoprim/sulfamethoxazole. The time interval between the transplant and the development of IA has been gradually growing over a period, because of use of peripheral blood stem cells instead of bone marrow or cord blood, with the use of myeloablative regimens and use of anti-fungal prophylaxis [31-33]. Infectious Disease Society of America (IDSA) recommends the use of voricanozole for treatment of Aspergillosis. In voricanozole refractory cases, Amphoteric B, Echinocandins, or combination of both can be used as treatment with effective results. Non-Aspergillus mold infections can be best treated with Amphotericin B, although posacanozole and voricanozole have been used with success in some susceptible strains of Zygomyectes and Fusarium species.

\section{Viral Infections}

\section{Cytomegalovirus (CMV)}

CMV infections are very common post HSCT, especially in patients who were CMV seropositive before BMT with a reactivation rate of 60 $70 \%$ [34]. The risk of acquiring the infection in a seronegative recipient from a CMV seropositive donor is about $30 \%$ [35]. Infection from CMV usually occur because of disruption in T-cell mediated cellular immunity, however, humoral immunity may play a role in disease severity.

Several CMV proteins such as IE-1, IE-2, and pp65 are targeted by the CD8+T-cell response. It has been proposed that innate immunity has role in development of CMV infection in patients with HSCT [36]. Following allogeneic HSCT, polymorphisms in chemokine receptor 5 and interleukin-10 are associated with CMV disease, whereas, polymorphisms in monocyte chemoattractant protein 1 are associated with CMV reactivation [37].
The risk for developing CMV infection or disease depends on many factors. CMV serostatus of the donor and recipient, type of transplant (allogeneic versus autologous), mismatched or unrelated donors, use of high dose corticosteroids for GVHD, use of T cell depleting agents (antitymocyte globuin and Alemtizumab), use of CD 34+ selected transplant, total body irradiation for conditioning are some of the known and important risk factors for CMV infection.

Clinically CMV infection can either present with CMV syndrome, characterized by fever of $38^{\circ} \mathrm{C}$, malaise, leukopenia, and thrombocytopenia, elevated liver enzymes with evidence of CMV viremia or may have involvement of an organ and have symptoms accordingly [38]. CMV pneumonia is one of the most serious manifestation of CMV infection with high mortality rates $[39,40]$. It presents as fever, nonproductive cough, hypoxia, and chest X-ray (CXR) reveals interstitial infiltrates. CMV gastroenteritis shares its clinical features with GVHD making the diagnosis challenging. Early endoscopic findings of erosion and oozing in suspected host aids in early diagnosis [41].

CMV retinitis, although it a rare phenomenon but its incidence have been increasing with use of unrelated match donors [42]. High CMV viral load ( $\geq 7.64 X 104$ copies $/ \mathrm{ml}$ ) and longer duration of CMV viremia seems to be important risk factor for developing retinitis in HSCT patients [43]. Routine retinal examination and screening of CMV retinitis is recommended in HSCT patients with CMV viremia for favourable visual outcomes [43].

Rarely CMV can affect the liver causing hepatitis or can involve brain-causing encephalitis. The symptoms are similar to other causes of encephalitis, like short-term memory deficit, cognitive impairment, confusion, lethargy, involvement of cranial nerves and paresis. Cerebrospinal Fluid (CSF) analysis shows, low cell count and glucose but high protein with presence of viral Deoxyribonucleic acid (DNA) confirming the diagnosis. Late onset of such infections after HSCT can have unfavourable outcomes despite adequate therapy [44].

The serological test to detect the presence of CMV specific antibodies (IgG and $\operatorname{IgM}$ ) is used only to determine patients risk for developing infection post transplantation and has no role in making the diagnosis. Shell-vial test is a rapid culture technique to detect CMV proteins in cultured cells. It is highly useful on bronchoalveolar lavage (BAL) fluid in the diagnosing CMV pneumonia [45]. The presence of CMV protein PP65 in peripheral blood leukocytes is a rapid way of diagnosing $\mathrm{CMV}$ infection. However, polymerase chain reaction (PCR) is the most sensitive as well as specific test for CMV detection [46]. The detection of CMV mRNA by nucleic acid sequence-based amplification on blood samples is similarly useful as DNA quantitative PCR or pp65 antigenemia for guiding preemptive therapy after HSCT [47]. The presence of characteristic CMV “owl's eye" nuclear inclusions in histopathology specimens is useful in the diagnosis of invasive CMV disease.

Ganciclovir is the first line treatment for any CMV disease including pneumonia, gastroenteritis, retinitis or other disease manifestation. A combination therapy of ganciclovir with intravenous immunoglobulins (IVIG) is used for pneumonia but there is no role of IVIG in gastroenteritis $[48,49]$. However, a longer induction period of 3-4 weeks is required to treat gi symptoms. Intraocular ganciclovir and foscarnet has been used successfully for CMV retinitis [50]. Foscarnet, cidofovir can be used as alternative agents to ganciclovir.

Adoptive immunotherapy which consists of restoring cellular immunity by generating CMV specific T cells with different mechanism 
have shown some beneficial effect in transplanted patients, but the lack of knowledge on optimum dosing, technical challenges have precluded its use in clinical practice [51].

The main step in prevention of CMV infection and disease is to ideally have a seronegative donor for seronegative recipient candidates, thus reducing the rates of primary CMV infection. However, this might not be possible in circumstances where other relevant donor related factors such a HLA match may be considered more important.

However we can apply certain strategies such as using CMV seronegative or leukocyte-reduced blood products $[52,53]$.

Moreover, antivirals agents are being used extensively to prevent CMV infection either as prophylactic or preemptive therapy. Prophylactic treatment can be defined as the beginning of the therapy in all patients at risk whereas preemptive therapy is given at first evidence of CMV infection but prior to the disease manifestation. Both the strategies are equally good, but with the advancement in early detection of CMV infection with use of pp65 antigenemia and DNA PCR-based assays, preemptive therapy is preferred [54]. On the same note, preemptive therapy may allow a limited amount of viral replication, thus stimulating immune responses and thereby promoting CMV-specific immune reconstitution [55].

Extensive weekly monitoring is required up to 100 days post transplant if preemptive therapy is to be considered in HSCT patients by both PCR and antigenemia assay [56,57]. However, after 100 days post transplant, the ideal duration and frequency of CMV infection monitoring have not been determined [58].

In special population who had CMV disease prior to transplant has higher mortality rate and thus require very close monitoring or prophylaxis with ganciclovir or foscarnet [35,59].

Ganciclovir is the first drug of choice for both prophylactic and preemptive treatment at a dose of $5 \mathrm{mg} / \mathrm{kg}$ intravenous, twice a day. The duration of the treatment is for minimum 2-3 weeks and until the indicator test is negative [35]. Even though ganciclovir is the first treatment choice, it has not shown to improve overall survival [60]. Neutropenia is one of the side effects of the therapy and occurs in upto $30 \%$ of patients with HSCT, thus increasing risk of other bacterial and viral infections [61]. Ganciclovir use in patients with compromised renal function requires drug monitoring. Valganciclovir, cidofovir and foscarnet are other second line agents used for this purpose.

\section{Human Herpes Virus (HHV) - 6, 7, 8 infections}

Human Herpes Virus (HHV) 6 infection in most cases of the HSCT is a consequence of reactivation [62]. The prevalence of HHV reactivation ranges from 40 to $60 \%$ in HSCT patients and usually occurs in 2-4 weeks $[63,64]$. Multiple risk factors are associated with HHV 6 reactivation including sex mismatched transplant, cord blood transplant, younger age, conditioning regimen, acute GVHD, and the type of prophylactic treatment used for GVHD [64,65]. Most well documented clinical association of HHV-6 is with encephalitis. It may present as frank encephalopathy or slow cognitive decline with detection of HHV 6 DNA in the CSF [66-69]. ). It is seen 1-2 months after transplantation and presents as profound memory loss, seizures, hyponatremia, and significant mesial-temporal lobe abnormalities on MRI [70,71]. These are mainly seen in recipient of HLA mismatched allergenic HSCT. HHV-6 is also associated with bone marrow suppression, acute GVHD and CMV reactivation. It is associated with high mortality and in survivors with residual neurological compromise $[69,72,73]$. Few studies have shown association of HHV-6 with pneumonitis, however, its causal effect and pathogenesis have not been well-understood [74]. DNA PCR is used for diagnosis and also to distinguish HHV-6A/B variants whereas, reverse transcription can detect active infection and replication $[62,74]$.

Ganciclovir and foscarnet have been used for treatment and prophylaxis based on small studies, however no RCT are available [7577]. Duration of therapy remains controversial but may be considered for about three weeks or until the peripheral blood HHV-6 PCR is undetectable.

HHV 7- The incidence of HHV-7 infection post HSCT has been noted to be in a range of $40 \%-47 \%$ [78-80]. Some of the risk factors and spectrum of clinical features such as encephalitis is similar to other viral infections associated with HSCT as described above [80,81]. However, Wang et al saw no relationship of HHV-7 with transplant related complications such as acute GVHD, CMV and HHV-6 infection [80], which may be in contrast to other reported studies 82. Major problem seen with this infection was delayed neutrophil engraftment [82], but Chan et al. [83] showed no statistically significant difference between HHV 7 positive and negative patients with issues of neutrophil or platelet engraftment. Diagnosis is made with PCR and ganciclovir remains the first line for treatment and prophylaxis.

HHV-8- The well known disease caused by HHV-8 is Kaposi's sarcoma (KS) and only few cases have been reported in HSCT patients [84]. It has not been well understood that KS is consequence of reactivation or due to seroconversion after BMT [84]. Even after seroconversion 'of seronegative recepients, no clinically significant events were seen in 6 year follow up [85].

\section{Herpes Simplex Virus (HSV)}

HSV stays repressed in neuronal cell in a state of latency until it is reactivated that leads to genomic expression, replication, and release of HSV. This is then followed by anterograde transport along the neuronal axons.

Host responses influence the acquisition, state of latency, frequency of recurrences and severity of infection. Though both antibody and cellmediated reactions are important, patients' with defective cell-mediated immunity experience more severe form of HSV infections than those with defect in humoral immunity. Surface viral glycoproteins are targets for antibodies that mediate antibody-dependent cell-mediated cytotoxicity. Maximal protection usually requires the activation of cytotoxic T cells.

All transplant candidates should be tested for serum anti-HSV IgG before transplant, though type specific testing is not required. To prevent transmission of HSV to HSCT recipients, contact precaution is recommended for anyone with primary, disseminated or severe mucocutaneous HSV throughout the course of illness.

Clinically, HSV may present as mucositis, genital herpes, esophagitis or pneumonia. Clinically apparent disease is seen within 2 - 3 weeks of transplant and is mainly due to reactivation for the latent virus. Risk of disease and need for prophylaxis is based on the serologic status of the recipient [86]. HSV infections have been observed in up to 80 percent of seropositive patients if prophylaxis is not given [87].

Acyclovir is used for prophylaxis and valacyclovir is an alternative for all HSV-seropositive allogeneic recipients [88-92]. Prophylaxis is started with conditioning therapy and continues until engraftment occurs or until mucositis resolves, whichever is longer, or $\approx 30$ days after HSCT [91]. It is given $200 \mathrm{mg}$ orally three times a day or 250 
Citation: Kedia S, Acharya PS, Mohammad F, Nguyen H, Asti D, et al. (2013) Infectious Complications of Hematopoietic Stem Cell Transplantation. J Stem Cell Res Ther S3:002. doi:10.4172/2157-7633.S3-002

$\mathrm{mg} / \mathrm{m} 2$ intravenously every 12 hours [93]. "Rebound" reactivation may occur with discontinuation of acyclovir so the optimal duration of prophylaxis remains controversial93. Valacyclovir is given 500 mg orally twice daily. Patient on other antivirals (e.g. foscarnet, valganciclovir, cidofovir) for any other reasons will not need acyclovir prophylaxis. Routine acyclovir prophylaxis is not indicated for HSV-seronegative HSCT recipients, even when the donor is HSV seropositive. Foscarnet is the drug of choice for resistant disease and cidofovir is an alternative. Low-dose prophylaxis or intermittent duration of therapy or treatment in HSV-seronegative donors confers risk of developing acyclovir resistant strains [94-96]. For patients with frequent recurrences of HSV infection- prophylaxis lasting more than one month may be considered.

\section{Epstein Barr Virus (EBV)}

Both donors and candidates should be tested for serum anti-EBV IgG Antibodies before transplant to assess the risk for primary EBV infection after HSCT. EBV infection is typically either reactivation of endogenous infection or transmission from donor graft [97].

The most important clinic syndrome associated with EBV in HSCT (mainly as primary infection) is Post Transplant Lymphoproliferative Disease (PTLD) [98]. As PTLD is usually seen in recipients with profound T-cell cytopenia (e.g. post T-cell depletion, anti-T-cell Antibody use, umbilical cord blood transplants and haploidentical transplants) $[97,99,100]$. EBV DNA load with quantitative PCR will help to classify patients at higher risk for PTLD [101-103].

EBV DNA load may rise as early as three weeks before disease onset. EBV DNA load monitoring will allows preemptive reduction in immunosuppression, which may be the first part in management. But due to the technical variation in estimating the risk for EBV related PTLD no firm recommendation have been made on the threshold for initiating preemptive therapy.

If there is no response to reduction in immunosuppression, preemptive treatment with rituximab can prevent PTLD (BII) [104]. Infusion of donor-derived, EBV-specific cytotoxic T Lymphocytes (CTL) has shown promise in the prophylaxis of EBV lymphoma among recipients of T-cell-depleted unrelated or mismatched allogeneic recipients $[105,106]$. Due to lack of strong evidence prophylaxis with antiviral agents is not recommended $[97,99,100]$.

\section{Conclusion}

Hematopoietic stem cell transplantation has been a path-breaking discovery in the field of oncology, proven to be a cure for many malignancies. However, there are various complications associated with, one of the many being the infectious complications described above. These can often be prevented by simple measures as frequent hand washing, vaccinations and appropriate donor screening. Nevertheless, in case of occurrence of these infections post transplant, there should be an early recognition of this complication and identification of the causative organism. Once diagnosed the treatment has to be one of an aggressive nature, with broad based antibiotic coverage until cultures and sensitivities are available after which de-escalation is a must to prevent any further antibiotics resistance.

\section{References}

1. Thomas ED, Storb R (1970) Technique for human marrow grafting. Blood 36: 507-515.

2. Schmitz N, Beksac M, Hasenclever D, Bacigalupo A, Ruutu T, et al. (2002) Transplantation of mobilized peripheral blood cells to HLA-identical siblings with standard-risk leukemia. Blood 100: 761-767.
3. Gluckman E, Rocha V, Boyer-Chammard A, Locatelli F, Arcese W, et al (1997) Outcome of cord-blood transplantation from related and unrelated donors. Eurocord Transplant Group and the European Blood and Marrow Transplantation Group. N Engl J Med 337: 373-381.

4. Bensinger W, Singer J, Appelbaum F, Lilleby K, Longin K, et al. (1993) Autologous transplantation with peripheral blood mononuclear cells collected after administration of recombinant granulocyte stimulating factor. Blood 81 : 3158-3163.

5. Appelbaum FR, Herzig GP, Ziegler JL, Graw RG, Levine AS, et al. (1978) Successful engraftment of cryopreserved autologous bone marrow in patients with malignant lymphoma. Blood 52: 85-95.

6. http://bloodcell.transplant.hrsa.gov/research/transplant_data/index.html

7. Finberg R FJ (2012) Infectious Diseases, Section 3. Clinical Syndromes Health Care-Associated Infections. In: Dan L. Longo ASF, Dennis L. Kasper Stephen L. Hauser, J.L. Jameson, J. Loscalzo, Eds, ed. Infections in Transplant Recipients, Infections in Hematopoietic Stem Cell Transplant Recipients. 18th ed ed: McGraw-Hill.

8. Wintrobe's Clinical Hematology-Hematopoietic Stem Cell Transplantation Volume 1 > Part III.

9. Bearman SI, Appelbaum FR, Back A, Petersen FB, Buckner CD, et al (1989) Regimen-related toxicity and early posttransplant survival in patients undergoing marrow transplantation for lymphoma. J clin oncol 7: 1288-1294.

10. Vera-Llonch M, Oster G, Ford CM, Lu J, Sonis S (2007) Oral mucositis and outcomes of allogeneic hematopoietic stem-cell transplantation in patients with hematologic malignancies. Support Care Cancer 15: 491-496.

11. Martin PJ (1992) Determinants of engraftment after allogeneic marrow transplantation. Blood 79: 1647-1650.

12. Zaucha JM, Zellmer E, Georges G, Little MT, Storb R, et al. (2001) G-CSFmobilized peripheral blood mononuclear cells added to marrow facilitates engraftment in nonmyeloablated canine recipients: CD3 cells are required. Biol Blood Marrow Transplant 7: 613-619.

13. Thomson BG, Robertson KA, Gowan D, Heilman D, Broxmeyer HE, et al (2000) Analysis of engraftment, graft-versus-host disease, and immune recovery following unrelated donor cord blood transplantation. Blood 96: 27032711.

14. Tomblyn M, Chiller T, Einsele H, Gress R, Sepkowitz K, et al. (2009) Guidelines for preventing infectious complications among hematopoietic cell transplantation recipients: a global perspective. Biol Blood Marrow Transplant 15: $1143-1238$.

15. Dykewicz CA (2001) Guidelines for preventing opportunistic infections among hematopoietic stem cell transplant recipients: focus on community respiratory virus infections. Biol Blood Marrow Transplant 7 Suppl: 19S-22S.

16. Wingard JR, Hsu J, Hiemenz JW (2010) Hematopoietic stem cell transplantation: an overview of infection risks and epidemiology. Infect Dis Clin North Am 24: 257-272.

17. Zhanel GG, Wiebe R, Dilay L, Thomson K, Rubinstein E, et al. (2007) Comparative review of the carbapenems. Drugs 67: 1027-1052.

18. Pizzo PA, Robichaud KJ, Gill FA, Witebsky FG (1982) Empiric antibiotic and antifungal therapy for cancer patients with prolonged fever and granulocytopenia. Am J Med 72: 101-111.

19. Gyorkos TW, Genta RM, Viens P, MacLean JD (1990) Seroepidemiology of Strongyloides infection in the Southeast Asian refugee population in Canada. Am J Epidemiol 132: 257-264.

20. Keiser PB, Nutman TB (2004) Strongyloides stercoralis in the Immunocompromised Population. Clin Microbiol Rev 17: 208-217.

21. Hovi L, Saarinen-Pinkala UM, Vettenranta K, Saxen H (2000) Invasive fungal infections in pediatric bone marrow transplant recipients: single center experience of 10 years. Bone Marrow Transplant 26: 999-1004.

22. Dictar MO, Maiolo E, Alexander B, Jacob N, Veron MT (2000) Mycoses in the transplanted patient. Med Mycol 38: 251-258.

23. Ribaud P, Chastang C, Latge JP, Baffroy-Lafitte L, Parquet N, et al. (1999) Survival and prognostic factors of invasive aspergillosis after allogeneic bone marrow transplantation. Clin Infect Dis 28: 322-330.

24. O’Brien SN, Blijlevens NM, Mahfouz TH, Anaissie EJ (2003) Infections in 
Citation: Kedia S, Acharya PS, Mohammad F, Nguyen H, Asti D, et al. (2013) Infectious Complications of Hematopoietic Stem Cell Transplantation. J Stem Cell Res Ther S3:002. doi:10.4172/2157-7633.S3-002

patients with hematological cancer: recent developments. Hematology Am Soc Hematol Educ Program 438-472.

25. Nucci M, Marr KA, Queiroz-Telles F, Martins CA, Trabasso P, et al. (2004) Fusarium infection in hematopoietic stem cell transplant recipients. Clin Infect Dis 38: $1237-1242$

26. Berenguer J, Rodriguez-Tudela JL, Richard C, Alvarez M, Sanz MA, et al. (1997) Deep infections caused by Scedosporium prolificans. A report on 16 cases in Spain and a review of the literature. Scedosporium Prolificans Spanish Study Group. Medicine (Baltimore) 76: 256-265.

27. Hachem R, Hanna H, Kontoyiannis D, Jiang Y, Raad I (2008) The changing epidemiology of invasive candidiasis: Candida glabrata and Candida krusei as the leading causes of candidemia in hematologic malignancy. Cancer 112 2493-2499.

28. Redding SW, Marr KA, Kirkpatrick WR, Coco BJ, Patterson TF (2004) Candida glabrata sepsis secondary to oral colonization in bone marrow transplantation. Med Mycol 42: 479-481.

29. Westbrook SD, Kirkpatrick WR, Freytes CO, Toro JJ, Bernardo S, et al. (2007) Candida krusei sepsis secondary to oral colonization in a hemopoietic stem cell transplant recipient. Medical Mycol 45: 187-190.

30. Robenshtok E, Gafter-Gvili A, Goldberg E, Weinberger M, Yeshurun M, et al. (2007) Antifungal prophylaxis in cancer patients after chemotherapy or hematopoietic stem-cell transplantation: systematic review and meta-analysis. J Clin Oncol 25: 5471-5489.

31. Marr KA, Carter RA, Crippa F, Wald A, Corey L (2002) Epidemiology and outcome of mould infections in hematopoietic stem cell transplant recipients. Clin Infect Dis 34: 909-917.

32. Grow WB, Moreb JS, Roque D, Manion K, Leather H, et al. (2002) Late onset of invasive aspergillus infection in bone marrow transplant patients at a university hospital. Bone Marrow Transplant 29: 15-19

33. Fukuda T, Boeckh M, Carter RA, Sandmaier BM, Maris MB, et al. (2003) Risks and outcomes of invasive fungal infections in recipients of allogeneic hematopoietic stem cell transplants after nonmyeloablative conditioning. Blood 102: 827-833.

34. Boeckh M, Ljungman P (2009) How we treat cytomegalovirus in hematopoietic cell transplant recipients. Blood 113: 5711-5719.

35. Ljungman P, Hakki M, Boeckh M (2011) Cytomegalovirus in hematopoietic stem cell transplant recipients. Hematol Oncol Clin North Am 25: 151-169.

36. Zaia JA, Sun JY, Gallez-Hawkins GM, Thao L, Oki A, et al. (2009) The effect of single and combined activating killer immunoglobulin-like receptor genotypes on cytomegalovirus infection and immunity after hematopoietic cell transplantation. Biol Blood Marrow Transplant 15: 315-325.

37. Loeffler J, Steffens M, Arlt EM, Toliat MR, Mezger M, et al. (2006) Polymorphisms in the genes encoding chemokine receptor 5 , interleukin-10, and monocyte chemoattractant protein 1 contribute to cytomegalovirus reactivation and disease after allogeneic stem cell transplantation. J Clin Microbiol 44: 18471850.

38. Gerna G, Lilleri D, Furione M, Baldanti F (2011) Management of human cytomegalovirus infection in transplantation: validation of virologic cut-offs for preemptive therapy and immunological cut-offs for protection. New Microbiol 34: $229-254$

39. Konoplev S, Champlin RE, Giralt S, Ueno NT, Khouri I, et al. (2001) Cytomegalovirus pneumonia in adult autologous blood and marrow transplant recipients. Bone Marrow Transplant 27: 877-881.

40. Ljungman $P$ (1995) Cytomegalovirus pneumonia: presentation, diagnosis, and treatment. Semin Respir Infect 10: 209-215.

41. Kakugawa Y, Kami M, Matsuda T, Saito Y, Kim SW, et al. (2010) Endoscopic diagnosis of cytomegalovirus gastritis after allogeneic hematopoietic stem cell transplantation. World J Gastroenterol 16: 2907-2912.

42. Larsson K, Lonnqvist B, Ringden O, Hedquist B, Ljungman P (2002) CMV retinitis after allogeneic bone marrow transplantation: a report of five cases. Transpl Infect Dis 4: 75-79.

43. Jeon S, Lee WK, Lee Y, Lee DG, Lee JW (2012) Risk factors for cytomegalovirus retinitis in patients with cytomegalovirus viremia after hematopoietic stem cell transplantation. Ophthalmology 119: 1892-1898.

44. Candoni A, Simeone E, Buttignol S, Volpetti S, Lazzarotto T, et al. (2011)
Late onset cytomegalovirus encephalitis after reduced-intensity conditioning allogeneic SCT: an emerging neurological complication? Bone Marrow Transplant 46: 455-456.

45. Crawford SW, Bowden RA, Hackman RC, Gleaves CA, Meyers JD, et al. (1988) Rapid detection of cytomegalovirus pulmonary infection by bronchoalveolar lavage and centrifugation culture. Ann Intern Med 108: 180-185.

46. Boeckh M, Huang M, Ferrenberg J, Stevens-Ayers T, Stensland L, et al. (2004) Optimization of quantitative detection of cytomegalovirus DNA in plasma by real-time PCR. J Clin Microbiol 42: 1142-1148.

47. Gerna G, Lilleri D, Baldanti F, Torsellini M, Giorgiani G, et al. (2003) Human cytomegalovirus immediate-early mRNAemia versus pp65 antigenemia for guiding pre-emptive therapy in children and young adults undergoing hematopoietic stem cell transplantation: a prospective, randomized, open-labe trial. Blood 101: 5053-5060

48. Reed EC, Bowden RA, Dandliker PS, Lilleby KE, Meyers JD (1988) Treatment of cytomegalovirus pneumonia with ganciclovir and intravenous cytomegalovirus immunoglobulin in patients with bone marrow transplants. Ann Intern Med 109 783-788.

49. Ljungman $\mathrm{P}$, Cordonnier $\mathrm{C}$, Einsele $\mathrm{H}$, Bender-Götze $\mathrm{C}$, Bosi $\mathrm{A}$, et al. (1998) Use of intravenous immune globulin in addition to antiviral therapy in the treatment of CMV gastrointestinal disease in allogeneic bone marrow transplant patients: a report from the European Group for Blood and Marrow Transplantation (EBMT). Infectious Diseases Working Party of the EBMT. Bone Marrow Transplant 21: 473-476.

50. Okamoto T, Okada M, Mori A, Saheki K, Takatsuka H, et al. (1997) Successfu treatment of severe cytomegalovirus retinitis with foscarnet and intraocular injection of ganciclovir in a myelosuppressed unrelated bone marrow transplant patient. Bone Marrow Transplant 20: 801-803.

51. Einsele H, Kapp M, Grigoleit GU (2008) CMV-specific T cell therapy. Blood Cells Mol Dis 40: 71-75.

52. Bowden RA, Slichter SJ, Sayers M, Weisdorf D, Cays M, et al. (1995) A comparison of filtered leukocyte-reduced and cytomegalovirus (CMV) seronegative blood products for the prevention of transfusion-associated CMV infection after marrow transplant. Blood 86: 3598-3603.

53. Ljungman P, Larsson K, Kumlien G, Aschan J, Barkholt L, et al. (2002) Leukocyte depleted, unscreened blood products give a low risk for CMV infection and disease in CMV seronegative allogeneic stem cell transplant recipients with seronegative stem cell donors. Scand J Infect Dis 34: 347-350.

54. Boeckh M, Gooley TA, Myerson D, Cunningham T, Schoch G, et al. (1996) Cytomegalovirus pp65 antigenemia-guided early treatment with ganciclovir versus ganciclovir at engraftment after allogeneic marrow transplantation: a randomized double-blind study. Blood 88: 4063-4071.

55. Li CR, Greenberg PD, Gilbert MJ, Goodrich JM, Riddell SR (1994) Recovery of HLA-restricted cytomegalovirus (CMV)-specific T-cell responses after allogeneic bone marrow transplant: correlation with CMV disease and effect of ganciclovir prophylaxis. Blood 83: 1971-1979.

56. Ljungman $P$, Reusser $P$, de la Camara R, Einsele $H$, Engelhard $D$, et al (2004) Management of CMV infections: recommendations from the infectious diseases working party of the EBMT. Bone Marrow Transplant 33: 1075-1081.

57. Liu YC, Lu PL, Hsiao HH, Chang CS, Liu TC, et al. (2012) Cytomegalovirus infection and disease after allogeneic hematopoietic stem cell transplantation: experience in a center with a high seroprevalence of both CMV and hepatitis B virus. Annals of hematology 91: 587-595.

58. Peggs KS, Preiser W, Kottaridis PD, McKeag N, Brink NS, et al. (2000) Extended routine polymerase chain reaction surveillance and pre-emptive antiviral therapy for cytomegalovirus after allogeneic transplantation. $\mathrm{Br} J$ Haematol 111: 782-790.

59. Fries BC, Riddell SR, Kim HW, Corey L, Dahlgren C, et al. (2005) Cytomegalovirus disease before hematopoietic cell transplantation as a risk for complications after transplantation. Biol Blood Marrow Transplant 11: 136-148.

60. Winston DJ, Ho WG, Bartoni K, Du Mond C, Ebeling DF, et al. (1993) Ganciclovir prophylaxis of cytomegalovirus infection and disease in allogeneic bone marrow transplant recipients. Results of a placebo-controlled, doubleblind trial. Ann Intern Medicine 118: 179-184.

61. Salzberger B, Bowden RA, Hackman RC, Davis C, Boeckh M (1997) Neutropenia in allogeneic marrow transplant recipients receiving ganciclovir for 
Citation: Kedia S, Acharya PS, Mohammad F, Nguyen H, Asti D, et al. (2013) Infectious Complications of Hematopoietic Stem Cell Transplantation. J Stem Cell Res Ther S3:002. doi:10.4172/2157-7633.S3-002

prevention of cytomegalovirus disease: risk factors and outcome. Blood 90: 2502-2508.

62. Zerr DM (2012) Human herpesvirus 6 (HHV-6) disease in the setting of transplantation. Curr Opin Infect Dis 25: 438-444.

63. Wang LR, Dong LJ, Lu DP (2006) [Prevalence of human herpesvirus-6 in allogeneic hematopoietic stem cell transplant recipients in correlation with cytomegalovirus infection]. Zhongguo shi yan xue ye xue za zhi 14: 1204-1209.

64. Zerr DM, Corey L, Kim HW, Huang ML, Nguy L, et al. (2005) Clinical outcomes of human herpesvirus 6 reactivation after hematopoietic stem cell transplantation. Clin Infectious Dis 40: 932-940.

65. Jeulin H, Agrinier N, Guery M, Salmon A, Clément L, et al. (2013) Human Herpesvirus 6 Infection After Allogeneic Stem Cell Transplantation: Incidence, Outcome, and Factors Associated With HHV-6 Reactivation. Transplantation 95: $1292-1298$

66. Wang FZ, Linde A, Hagglund H, Testa M, Locasciulli A, et al. (1999) Human herpesvirus 6 DNA in cerebrospinal fluid specimens from allogeneic bone marrow transplant patients: does it have clinical significance? Clin Infect Dis 28: $562-568$

67. Zerr DM, Fann JR, Breiger D, Boeckh M, Adler AL, et al. (2011) HHV-6 reactivation and its effect on delirium and cognitive functioning in hematopoietic cell transplantation recipients. Blood 117: 5243-5249.

68. Wainwright MS, Martin PL, Morse RP, Lacaze M, Provenzale JM, et al. (2001) Human herpesvirus 6 limbic encephalitis after stem cell transplantation. Ann Neurol 50: 612-619.

69. Zerr DM (2006) Human herpesvirus 6 and central nervous system disease in hematopoietic cell transplantation. J Clin Virol 37: S52-56.

70. Seeley WW, Marty FM, Holmes TM, Upchurch K, Soiffer RJ, et al. (2007) Posttransplant acute limbic encephalitis: clinical features and relationship to HHV6. Neurology 69: 156-165

71. Gorniak RJ, Young GS, Wiese DE, Marty FM, Schwartz RB (2006) MR imaging of human herpesvirus-6-associated encephalitis in 4 patients with anterograde amnesia after allogeneic hematopoietic stem-cell transplantation. AJNR Am J Neuroradiol 27: 887-891.

72. Muta T, Fukuda T, Harada M (2009) Human herpesvirus- 6 encephalitis in hematopoietic SCT recipients in Japan: a retrospective multicenter study. Bone Marrow Transplant 43: 583-585

73. Sakai R, Kanamori H, Motohashi K, Yamamoto W, Matsuura S, et al. (2011) Long-term outcome of human herpesvirus- 6 encephalitis after allogeneic stem cell transplantation. Biol Blood Marrow Transplant 17: 1389-1394.

74. Hentrich M, Oruzio D, Jager G, Schlemmer M, Schleuning M, et al. (2005) Impact of human herpesvirus-6 after haematopoietic stem cell transplantation. Br J Haematol 128: 66-72.

75. Rapaport D, Engelhard D, Tagger G, Or R, Frenkel N (2002) Antiviral prophylaxis may prevent human herpesvirus-6 reactivation in bone marrow transplant recipients. Transpl Infect Dis 4: 10-16.

76. Tokimasa S, Hara J, Osugi Y, Ohta H, Matsuda Y, et al. (2002) Ganciclovir is effective for prophylaxis and treatment of human herpesvirus- 6 in allogeneic stem cell transplantation. Bone Marrow Transplant 29: 595-598.

77. Ishiyama K, Katagiri T, Ohata K, Hosokawa K, Kondo Y, et al. (2012) Safety of pre-engraftment prophylactic foscarnet administration after allogeneic stem cell transplantation. Transpl Infect Dis 14: 33-39.

78. Hubacek P, Sedlacek P, Keslova P, Formankova R, Stary J, et al. (2008) Incidence of HHV7 in donors and recipients of allogeneic hematopoietic stem cell transplantation. Pediatr Blood Cancer 50: 935.

79. Dzieciatkowski T, Przybylski M, Basak GW, Torosian T, Jedrzejczak WW, et al. (2011) Human herpesvirus 7 in allogeneic hemopoietic stem cell transplant recipients in the central clinical hospital in Warsaw: a three-year survey. Intervirology 54: 25-29.

80. Wang LR, Dong LJ, Lu DP (2007) [Human herpesvirus 7 infection in patients after allogeneic hematopoietic stem cell transplantation]. Zhonghua Yi Xue Za Zhi 87: 2113-2116.

81. Chan PK, Chik KW, To KF, Li CK, Shing MM, et al. (2002) Case report: human herpesvirus 7 associated fatal encephalitis in a peripheral blood stem cell transplant recipient. J Medical Virol 66: 493-496.
82. Chan PK, Peiris JS, Yuen KY, Liang RH, Lau YL, et al. (1997) Human herpesvirus- 6 and human herpesvirus-7 infections in bone marrow transplant recipients. J Med Virol 53: 295-305.

83. Chan PK, Li CK, Chik KW, Lee V, Shing MM, et al. (2004) Risk factors and clinical consequences of human herpesvirus 7 infection in paediatric haematopoietic stem cell transplant recipients. J Med Virol 72: 668-674.

84. Luppi M, Barozzi P, Rasini V, Torelli G (2002) HHV-8 infection in the transplantation setting: a concern only for solid organ transplant patients? Leuk Lymphoma 43: 517-522.

85. Gentile G, Capobianchi A, Volpi A, Palù G, Pica F, et al. (2005) Human herpesvirus 8 DNA in serum during seroconversion in allogeneic bone marrow transplant recipients. J Natt Cancer Inst 97: 1008-1011.

86. Knowles WA (2006) Discovery and epidemiology of the human polyomaviruses BK virus (BKV) and JC virus (JCV). Adv Exp Med Biol 577: 19-45.

87. Egli A, Infanti L, Dumoulin A, Buser A, Samaridis J, et al. (2009) Prevalence of polyomavirus BK and JC infection and replication in 400 healthy blood donors. J Infect Dis 199: 837-846.

88. Saral R, Burns WH, Laskin OL, Santos GW, Lietman PS (1981) Acyclovir prophylaxis of herpes-simplex-virus infections. N Engl J Med 305: 63-67.

89. Gluckman E, Lotsberg J, Devergie A, Zhao XM, Melo R, et al. (1983) Prophylaxis of herpes infections after bone-marrow transplantation by oral acyclovir. Lancet 2: 706-708.

90. Wade JC, Newton B, McLaren C, Flournoy N, Keeney RE, et al. (1982) Intravenous acyclovir to treat mucocutaneous herpes simplex virus infection after marrow transplantation: a double-blind trial. Ann Intern Med 96: 265-269.

91. Wade JC, Newton B, Flournoy N, Meyers JD (1984) Oral acyclovir for prevention of herpes simplex virus reactivation after marrow transplantation. Ann Intern Med100: 823-828.

92. Johnson JR, Egaas S, Gleaves CA, Hackman R, Bowden RA (1992) Hepatitis due to herpes simplex virus in marrow-transplant recipients. Clin Infect Dis 14 38-45.

93. Bofill-Mas S, Formiga-Cruz M, Clemente-Casares P, Calafell F, Girones $R$ (2001) Potential transmission of human polyomaviruses through the gastrointestinal tract after exposure to virions or viral DNA. J Virol 75: 1029010299.

94. Erard V, Wald A, Corey L, Leisenring WM, Boeckh M (2007) Use of long-term suppressive acyclovir after hematopoietic stem-cell transplantation: impact on herpes simplex virus (HSV) disease and drug-resistant HSV disease. J Infect Dis 196: $266-270$.

95. Langston AA, Redei I, Caliendo AM, Somani J, Hutcherson D, et al. (2002) Development of drug-resistant herpes simplex virus infection after haploidentical hematopoietic progenitor cell transplantation. Blood 99: 1085-1088.

96. Nichols WG, Boeckh M, Carter RA, Wald A, Corey L (2003) Transferred herpes simplex virus immunity after stem-cell transplantation: clinical implications. Infect Dis 187: 801-808.

97. Zutter MM, Martin PJ, Sale GE, Shulman HM, Fisher L, et al. (1988) EpsteinBarr virus lymphoproliferation after bone marrow transplantation. Blood 72 520-529.

98. Buchsbaum RJ, Fabry JA, Lieberman J (1996) EBV-specific cytotoxic T lymphocytes protect against human EBV-associated lymphoma in scid mice. Immunol Lett 52: 145-152.

99. Shapiro RS, McClain K, Frizzera G, Gajl-Peczalska KJ, Kersey JH, et al. (1988) Epstein-Barr virus associated B cell lymphoproliferative disorders following bone marrow transplantation. Blood 71: 1234-1243.

100. Gerritsen EJ, Stam ED, Hermans J (1996) Risk factors for developing EBVrelated $B$ cell lymphoproliferative disorders (BLPD) after non-HLA-identical BMT in children. Bone Marrow Transplant 18: 377-382.

101.Lucas KG, Burton RL, Zimmerman SE, Wang J, Cornetta KG, et al. (1998) Semiquantitative Epstein-Barr virus (EBV) polymerase chain reaction for the determination of patients at risk for EBV-induced lymphoproliferative disease after stem cell transplantation. Blood 91: 3654-3661.

102. Gustafsson A, Levitsky V, Zou JZ, Frisan T, Dalianis T, et al. (2000) EpsteinBarr virus (EBV) load in bone marrow transplant recipients at risk to develop posttransplant lymphoproliferative disease: prophylactic infusion of EBVspecific cytotoxic T cells. Blood 95: 807-814. 
Citation: Kedia S, Acharya PS, Mohammad F, Nguyen H, Asti D, et al. (2013) Infectious Complications of Hematopoietic Stem Cell Transplantation. J Stem Cell Res Ther S3:002. doi:10.4172/2157-7633.S3-002

Page 8 of 8

103. van Esser JW, van der Holt B, Meijer E, Niesters HG, Trenschel R, et al. (1994) Epstein-Barr virus (EBV) reactivation is a frequent event after allogeneic stem cell transplantation (SCT) and quantitatively predicts EBV-lymphoproliferative disease following T-cell--depleted SCT. Blood 98: 972-978.

104. Meerbach A, Wutzler P, Hafer R, Zintl F, Gruhn B (2008) Monitoring of Epstein-Barr virus load after hematopoietic stem cell transplantation for early intervention in post-transplant lymphoproliferative disease. J Med Virol 80: $441-454$.
105.Papadopoulos EB, Ladanyi M, Emanuel D, Mackinnon S, Boulad F, et al. (1994) Infusions of donor leukocytes to treat Epstein-Barr virus-associated lymphoproliferative disorders after allogeneic bone marrow transplantation. $\mathrm{N}$ Engl J Med 330: 1185-1191.

106. Rooney CM, Smith CA, Ng CY, Loftin SK, Sixbey JW, et al. (1998) Infusion of cytotoxic $T$ cells for the prevention and treatment of Epstein-Barr virus-induced lymphoma in allogeneic transplant recipients. Blood 92: 1549-1555.

This article was originally published in a special issue, Hematopoietic stem cell transplantation handled by Editor(s). Dr. Porrata Luis F, Mayo Clinic Transplant Center, USA 